\title{
A civilisation among the fields
}

'Co-operation is gradually altering the character of Irish rural life,' Æ opined in a 1905 Irish Homestead editorial, 'but we are only at the beginning'. Rural Irish communities possessed the potential to bring about a new type of economy whereby 'everybody and every industry connected with agriculture' formed the foundations of a 'co-operative state'. A far from impartial observer on this matter, Æ envisaged that a co-operative commonwealth might be brought about through the expansion of co-operative societies so they might eventually produce and distribute all goods for market. Æ's work for the IAOS, first as an organiser of credit societies and subsequently Homestead editor, trained him to leaven his idealism with pragmatism when it came to the hard work required to win farmers over to the co-operative model. As he wrote: 'we don't believe the last day will come, or any new Jerusalem appear in the heavens until men have made the most there is to be made out of this old world'. The establishment of a co-operative society represented an occasion pregnant with possibility, as it formed a nucleus from which a reinvigorated local community might flourish. At the centre of each village would be 'the co-operative creamery, with the manager's house beside it ... There will be a village hall where committee meetings will be held, lectures delivered, dramatic performances, concerts, and dances. ${ }^{1}$ The dissemination of the co-operative principle among the farmers of Ireland amounted to a concerted attempt to nurture and build a new type of state in Ireland - one incubated within the rural community.

Co-operative activists viewed their task as the creation of a modern, dynamic 'civilisation among the fields', as they looked to conduct social change. ${ }^{2}$ This chapter recovers the lost ideological thread of Irish co-operation and argues that the IAOS's influence over the countryside generated new forms of agricultural knowledge and expertise that went on to shape the nature of the Irish state. Under the IAOS's direction, the numbers of co-operative societies increased over the next twenty years - a mixture of co-operative creameries, agricultural stores, credit societies and poultry societies. The resultant portrait of the co-operative movement is one of a voluntary, nominally non-state organisation that exerted considerable influence over the economy and character of an emergent nation-state. 
I start with an examination of the IAOS leadership and the focus then moves between the national and local layers of the co-operative movement from the 1890 s onwards. In this latter regard, understanding the role of the co-operative organiser is crucial. The IAOS's Executive Committee consisted of landlords, Catholic clergy, industrialists, Unionists and Nationalists. However, the prominence of landlords left the executive vulnerable to criticism in its earliest years, which in turn limited the effectiveness of the organiser in the field. In order for a new society to be established and succeed, it was crucial that support came from across the local community. While the establishment of new societies relied upon the support granted by traditional authority figures such as the priest and landlord, the co-operative society also contributed to the creation of a new social caste of managers and administrators. ${ }^{3}$ The work of professional co-operative organisers proved to be of particular importance as these, more than any other individual, shaped the growth of the movement. Organisers constantly moved between the national and local levels of the co-operative organisation and therefore played a critical role in connecting the leadership to the members. They policed individual societies through visits and inspections, communicated new ideas associated with agriculture, and produced reports on individual societies for the Dublin headquarters. Although few in number organisers acted as the crucial figures that moved between and linked together the network of societies.

The idea that the co-operative principle's introduction offered both an opportunity and means to achieve a positive transformation in the Irish countryside appeared obvious to visitors who wished to understand the peculiar social and political conditions of the country. In autumn 1897, the American Progressive and muckraking journalist, Henry Demarest Lloyd, toured Ireland and Britain to witness the work conducted 'in the field of production by co-operative societies'. Lloyd's fierce reputation as an investigative journalist stemmed from his publication of articles that warned against the dangers of unrestrained corporate power and monopolistic capitalism in the 1880s and 1890s. When Lloyd arrived, he expected scenes that fitted Ireland's reputation as 'the most distressing country in Europe ... with its sad faces by the roadside'. Instead, he encountered a country undergoing profound social change. The economic leadership shown by Plunkett and the IAOS left Lloyd impressed. He credited the improvements he witnessed to 'the light of co-operation ... one now finds Ireland - the land of famines and evictions ... further advanced in the organization of agricultural co-operation than England'. Similarly, Louis Paul-Dubois's 1908 travelogue cited the co-operative movement as a major source for potential national regeneration. The French sociologist viewed the movement as a key agent of education for Irish farmers and emphasised the co-operative movement's role in striving for social improvement. He believed it exerted a positive moral effect upon the population, inculcating values such as discipline, and the powerful notion of 'self-help by mutual help'. 5 This curious social phenomenon of rural co-operation noticed by international visitors such 
as Paul-Dubois and Lloyd reflected the conscious effort to reorganise Irish society completely, starting with the peasant and moving up through all levels of Irish social and political life.

As Leeann Lane has argued, the IAOS represented one way in which farmers might be morally reconstituted as a 'noble peasant of the cultural revival'. 6 Success in this mission required co-operators to fashion a coalition of interests that carried influence and authority with the rural population. Plunkett summarised this objective with an aphorism later adopted by rural reformers elsewhere: 'better farming, better business, better living'. By this, he meant that 'agriculture must be regarded as an industry, as a business, and as a life'. The most important of these maxims for the co-operative activist was the third. The improvement of agriculture through enhanced farming and business methods mattered as a 'means to better living'. Co-operative activists envisaged an ideal rural community where 'every member ... can be satisfied that remaining on the land does not imply being in the backwater of modern progress.' ${ }^{7}$ In the end, supporters believed the IAOS network contained the potential to revitalise rural communities and help prepare a new form of economic organisation to animate the Irish nation.

\section{The national organisation}

The IAOS's establishment led to the formation of a new coalition that played a prominent role in the direction of Irish social politics at the end of the nineteenth and early twentieth centuries. Plunkett wanted the IAOS to be a home for those who wanted to harmonise Irish society's diverse interest groups into a practical reality; a place where landlord and farmer, Nationalist and Unionist, rural and urban inhabitants worked towards a common goal of a more co-operative economy. Economic co-operation then, was more than just a business model. It offered a means through which social and political harmonisation might occur. The coalition that grew out of the labours to build a more co-operative country remained in constant flux, owing to the many controversies that affected the co-operative movement. At a local level, the societies under the IAOS umbrella consisted mainly of farmers, but also included landlords, clergy and new authority figures such as creamery managers and itinerant co-operative organisers who linked the co-operative network together.

Horace Plunkett remained intimately associated throughout his life with the organisation he started. He served as the first president of the IAOS from 1894 until his death in 1932, outside of a seven-year period when he served as Vice-President of the Department of Agriculture and Technical Instruction (DATI). Ever the patrician, Plunkett remained an unapologetic defender of the role played by members of the landlord class in the regeneration of Irish soil and society. His faith in the innate moral and intellectual superiority of his class made Plunkett a somewhat problematic leader for a movement committed to the 
pursuit of non-political interventions. The composition of the IAOS Executive was certainly an obvious target for criticism, although the story proved more complex at a local level. Plunkett's public statements on how landlords needed to retain a leadership role made this case easier. An outcome of land reforms enacted over previous decades saw the connection between tenant farmers and landlords weakened. Plunkett argued that 'the abolition of landlordism, so far from destroying the usefulness of the Irish gentry, really gives them their first opportunity, within the memory of living men, to fulfil the true functions of the aristocracy'. The gentry might no longer claim mastery of the land, but by virtue of their education and wealth they possessed special advantages they should use to promote socially harmonised rural communities in pursuit of common goals. $^{8}$

The repeated assertion of such noblesse oblige made it easy for critics of cooperation to attack the IAOS as a site of elitist politicking as Plunkett provided enemies with an easily caricatured stereotype of Irish landlords who looked to assert their superiority over farmers. Certainly, landlords dominated the IAOS leadership. Other members of the landlord class succeeded as IAOS president when Plunkett stepped down to serve as Vice-President of the DATI in 1900 - first Lord Monteagle and then Colonel Nugent Everard - until Plunkett returned to the position once again in 1907.

Despite the prominence given to landlords, the foundation of the IAOS did mark an attempt to fashion a new type of social partnership that ignored traditional lines of sectarian and political identities. Fr Thomas Finlay served as the VicePresident and actively promoted co-operative projects across Ireland. As a recognisable public intellectual, Finlay lent a cerebral credibility to the movement as he frequently engaged in debates with critics of the co-operative system, offered evidence to parliamentary inquiries on issues such as the provision of rural credit, engaged in labour politics and worked as Professor of Economics at University College Dublin. He also contributed to the vibrant journal culture of that period via a number of publications, as well as conceiving of the Irish Homestead. As someone well connected to members of the clergy throughout Ireland and with a reputation as a vocal nationalist Finlay helped to counter criticisms that the IAOS promoted the continuation of traditional Anglo-Irish influence. 'The make-up of the rest of the IAOS Committee reflected the effort to include a range of political and social opinions as Plunkett aimed to ensure nationalists occupied a place on the Executive. Alongside landlords such as Lord Monteagle and Walter MacMorrough Kavanagh were grandees drawn from the Irish Parliamentary Party tradition such as Thomas Sexton and Arthur Moore and also included, albeit briefly, the prominent MP and later Nationalist Party leader, John Redmond. ${ }^{10}$ However, Redmond resigned his position on the committee after a year when his brother, Willie, replaced him. 


\section{Catholicism and co-operation}

Plunkett immediately looked to attract the support of the Catholic hierarchy as a crucial step to win over the large numbers of Catholic farmers. An endorsement from the bishops might counter criticisms that the IAOS represented a landlord's league. Plunkett recognised the temporal power of the Catholic clergy during the time he worked for the Congested Districts Board (CDB) and the early years promoting co-operation for farmers. ${ }^{11}$ On the eve of the IAOS launch Plunkett aimed to secure the support of Archbishop William Walsh of Dublin for the venture. The timing was propitious. The IAOS's establishment occurred three years after the appearance of Pope Leo XIII's Papal Encyclical, Rerum Novarum. Pope Leo pleaded for greater Catholic engagement with social and economic issues. The inequalities created by capitalism and the threat posed by socialism threatened to tear apart modern society and an application of Catholic social teachings was required to mediate between these two forces. In an argument that appealed to the sensibilities of co-operators, Rerum Novarum outlined a moral vision in which all classes 'should dwell in harmony and agreement, so as to maintain the balance of the body politic'. ${ }^{12}$ This statement accorded with the principle of mutual economic interest across rural classes promoted by the IAOS. In April 1894, Plunkett thanked Walsh for his 'kind support of my new project' and pointed to the IAOS's compatibility with Catholic social teaching when he stated, 'I am sure that the principles we have laid down will harmonise with your Lordship's views upon economic and industrial questions in Ireland. ${ }^{13}$ The support granted to the work of co-operative organisation by prominent religious figures such as Walsh proved to be a useful tool for organisers to combat attacks. For example, in a dispute with a trader opposed to the extension of co-operative dairying in Tralee, Robert Anderson pointed to the fact Archbishop Walsh supported the extension of co-operation when he offered the farmers of Inch, County Wexford, a $£ 100$ interest-free loan towards the establishment of a co-operative creamery. $^{14}$

The courting of sympathetic bishops remained part of Plunkett's long-term strategy. In a letter to the Catholic Bishop of Elphin, John Clancy, Plunkett argued that 'the moral and social justification of the co-operative creamery is that its successful working calls for the exercise by the participants in the undertaking of certain qualities which we all wish to promote in Ireland'. ${ }^{15}$ In making this point, Plunkett attempted to stress the interest that all parties, both secular and religious, shared in the spread of co-operative businesses. What Plunkett viewed as the development of rural character might also be interpreted as the moral improvement of the bishop's Catholic subjects.

Attitudes towards co-operation among the hierarchy and the clergy proved uneven and remained ambiguous or even hostile. At a meeting of the bishops on 30 April 1895 the question over what extent 'priests should take an active 
part in the formation of Co-operative Creameries' was discussed. The bishops reached no definitive conclusion except for a deferred decision to prepare a memorandum of guidance at some stage in the future. ${ }^{16}$ As an indication of interest in the new movement, Bishop Patrick O'Donnell of Raphoe sat on the early IAOS Executive Committee. O'Donnell had ascended to the bishopric aged 32 and worked previously with Plunkett on the executive of the CDB, where they both shared an interest in ways to regenerate the economy to counteract poverty and emigration. Another important ally in the church was Bishop O'Dwyer of Limerick - a diocese where co-operative creameries managed to spread with great success. ${ }^{17}$ At a national level, the support of the clergy for the IAOS helped to broaden the appeal of economic co-operation. Yet tensions between the IAOS and the Church always threatened to surface. Although an architect of the fragile coalition between the Church and co-operative movement, Plunkett also proved himself a liability in upsetting this finely balanced alliance.

\section{Ireland in the new century}

Plunkett provided the IAOS's animating spirit but also acted as a weathervane for political controversy. He worked hard to bring along as many shades of political and social opinion behind the banner of the IAOS, but equally showed a tendency to squander this hard-earned goodwill. In 1904, he completed his major literary work, Ireland in the New Century. The book's publication became a source of substantial controversy that placed Plunkett and his movement within a maelstrom of highly publicised invective. In this work, one can find a distillation of Plunkett's idiosyncratic social, economic and political views. He offered readers a literary exposition of many of the familiar themes with which he was associated in public, such as emigration, rural decline and the need for a radical approach to agricultural modernisation. No one who followed Plunkett's past statements would have been shocked by his outline of the Irish Question as a social and economic matter rather than a political one. However, one chapter in the book criticised the malign economic effects of the Catholic Church in Ireland. Plunkett argued that a primary motivation for his belief in co-operative organisation resided in its capacity to affect improvement in the character of those whom it incorporated. He contrasted this with a prevalent Irish Catholic culture that prevented progress and denied prosperity. In particular, he criticised the 'excessive and extravagant church-building ... at the expense of poor communities' ${ }^{18}$ Friends recommended Plunkett not to publish this section of the book. Tenacious and convinced of his argument's correctness, Plunkett published the book with the chapter intact. When it appeared, it 'aroused a fierce and sometimes ill-informed controversy'. ${ }^{19}$

The controversy damaged many of the relationships, which Plunkett spent a great deal of time and energy to put in place. Any goodwill that existed between 
Plunkett and the IPP's leadership evaporated immediately. John Redmond, who worked fruitfully alongside Plunkett on the Recess Committee of 1896, launched a stinging attack upon the author in March 1904 while on a fundraising tour of the United States. Redmond claimed that Plunkett's plans for an industrial revival in Ireland amounted to 'quackery' and the book represented 'nothing more or less than an insidious effort to undermine the Home Rule movement'. ${ }^{20}$ The fallout with the Nationalist leader proved so toxic that Redmond wrote to the IAOS Secretary to 'remove his name from the list of past and present members of the Society ... and to assure him that no other use has been made of his name since his resignation'. ${ }^{21}$ Thus ended any hope of a rapprochement between the IAOS and the leaders of nationalist sentiment represented by the IPP.

Relations between Plunkett and sympathetic allies in the Church did survive in certain instances. For example, Bishop O'Dwyer's interest in questions about educational provision in Ireland brought him into regular correspondence with Plunkett. However, Ireland in the New Century placed a strain on this relationship. Plunkett defended his book to the Bishop of Limerick on the grounds that his 'attitude towards Catholicism has been profoundly misunderstood' and 'any careful reader of my book will see that, in view of the low economic state of our country and its high spiritual aspirations, my desire is to get the Catholic Church recognised as a powerful auxiliary to economic progress' ${ }^{22}$ Perhaps sincere in this view the fact remained that Plunkett's unrestrained criticism of the Church's influence over economic matters belied his undiplomatic side and tendency to provoke hostility. When they met in person, Plunkett found that the book 'made [O'Dwyer] very sore. But he remains generously friendly'. ${ }^{23}$ Plunkett also received private expressions of support from Dr Sheehan, the Bishop of Waterford, but 'nothing which could be taken as expressing approval of my views which he admits in private'. ${ }^{24}$

Despite occasions of support, the critical tone of Ireland in the New Century primarily unleashed controversy. Fr Barry, parish priest for Oldcastle, County Meath, attacked the book as 'rather the drivel of a charlatan than a universitytrained thinker' in the nationalist newspaper, Freeman's Journal. He called Plunkett's work 'mean and insidious' and set a template for further attacks from Catholic hierarchy and clergy. ${ }^{25}$ Barry's broadside precipitated Cardinal Logue's Pastoral in which the leader of the Irish Catholic Church condemned the book 'though he admits he has not read it'. ${ }^{26}$ Several months later, the rector of the Irish College in Rome, Monsignor Michael O'Riordan, responded to the controversial chapter of the book with the epic Catholicity and Progress in Ireland, which prolonged the controversy further. The controversy weakened Plunkett's authority at the DATI and provided further ammunition for those critics strongly opposed to the extension of the IAOS and the co-operative movement. Even Bishop O'Donnell, once a prominent champion of the IAOS, grew estranged from the movement as his relationship with Plunkett broke down. ${ }^{27}$ As Robert Anderson pithily 
recalled three decades after its publication, 'it cannot be said that the book made the task for us organisers any easier' ${ }^{28}$

\section{The Irish Homestead}

The IAOS established The Irish Homestead to propagandise the objectives and ideas of the co-operative movement. This proved to be a vital medium in countering the effects of bad publicity that co-operation and its advocates attracted. The first issue launched on the 9 March 1895 under Fr Tom Finlay's editorship. Already an experienced editor of journals such as the Lyceum and the New Ireland Review, he established the Homestead with finance obtained by Plunkett. Finlay edited the newspaper for its first two years with the aim to document 'the progress of agricultural co-operation' and provide readers with the unfolding 'chapters of the economic history of Ireland'. ${ }^{29}$ The Homestead offered readers a lively commentary on a wide range of social and political topics that ranged from instructive pieces on the importance of winter dairying to editorials on the Russian Revolution. The paper maintained an eclectic focus that encompassed national and international news, instruction on innovative farming methods, information about agricultural markets and news about individual societies, as well as literary pages that placed the journal within the contemporary cultural revival. The Irish Homestead was a weekly publication to which all societies were encouraged to subscribe as it provided news stories on agricultural innovations in other countries and thereby formed a vital link to a global co-operative forum. In its first years the IAOS subsidised the Homestead, but by 1904 the newspaper paid its own way and besides subscribers from its own societies - attracted an overseas readership in countries such as France, Germany, Finland, Canada, New Zealand and the United States. ${ }^{30}$

The growth of the movement during the 1890s led to conflict with economic opponents who published their attacks in the press. Fr Finlay understood the importance of a newspaper to promote the movement's progress and offer a public rebuke to such attacks in media. For example, a report on 'Horace Plunkett's Disorganization Society' in the Skibbereen Eagle described the movement as a 'scheme for the introduction of continental socialism'. The author advised farmers not to support the IAOS, which amounted to 'a mockery, a delusion, a snare' whose 'plain object' was 'to abolish shopkeepers, pig-buyers, cattle-dealers and the like'. ${ }^{31}$ The first editorial explained that the decision to publish a new journal stemmed from the fact that 'there is hardly any interest worth representing before the public which has not its organ in the Press ... A movement which is not supported by its own newspaper is in danger of being thought insignificant. If it cannot publish its message through the medium of its own press, it is in danger of not being listened to at all. ${ }^{32}$ The establishment of a co-operative society undoubtedly affected the interests of these listed professions as they were intended to act as a point for farmers to purchase farming necessities at wholesale prices 
and a means through which to sell their produce to customers at value closer to retail price. As outlined in the first issue of the Homestead:

No new movement of importance can make way without provoking hostility. It must necessarily affect the privileges of existing interests, and must expect to be denounced accordingly ... We take it as a sign of its progress that [the co-operative movement] is vehemently condemned by certain critics who have no share in its benefits. And we are prepared to gauge its progress by the violence of its opponents. ${ }^{33}$

Several editors worked on the paper in the decade before Plunkett appointed $Æ$ to carry out the duty in August 1905 . $Æ$ brought to the task an intellectual curiosity and poetic sensibility that made him an ideal candidate for the propagandist role. As recollected by George Moore in his irreverent memoir Hail and Farewell, Plunkett came to understand that 'a poet was necessary. ... If they could get a poet with some knowledge of detail (Plunkett reserved the right to dream to himself), the country might be awakened to the advantages of cooperation.' W.B. Yeats introduced Plunkett to the 'poet-accountant' who then offered $Æ$ a job as an organiser of credit societies. $Æ$ accepted, along with the present of a bicycle. ${ }^{34} \rightleftarrows$ 's grounding in the IAOS's practical work, in which he travelled across Ireland on his bicycle, made him intimately familiar with the conditions of rural Ireland, which intensified his belief in the necessity for a co-operative reorganisation of the economy. However, $Æ^{\prime}$ 's most important work for the IAOS occurred during his time at the helm of the Irish Homestead, which continued until the journal's incorporation within the Irish Statesman in 1922. His organisational experience grounded the theorising and arguments about Irish social affairs, economics and politics with which he filled the Homestead's pages. Under Æ's editorship, the Irish Homestead became a key part of the IAOS's strategy to promote its message among current and potential supporters. As Nicholas Allen observed, while Plunkett conceived of the Homestead as a platform to further the ideals of co-operation 'Russell's genius was to make this task intrinsic to a commentary on Irish life'. ${ }^{35}$

\section{Co-operation and the changing role of women}

The Homestead proved a highly provocative paper under Æ's editorship. One area in which he used the Homestead to spark a public debate was on the role of women in efforts to reorganise the countryside. The spread of the co-operative movement played a significant role in redrawing the working lives of rural women. In its earlier years the IAOS concentrated upon the spread of its societies, particularly creameries, and found little space to discuss and debate the transformations the co-operative system exerted upon the role of female labour. Throughout the nineteenth century, butter production was primarily a female-dominated industry. Production occurred in the home where it was either consumed or sold on to butter merchants. The introduction of creameries in the late nineteenth century 
immediately lowered female employment, with the co-operative system heavily implicated in the shift of butter making from a domestic industry into the new modern separating factory at the heart of a parish. Women remained largely absent within the labour structure of the creamery, rarely held a position on the committees, and were in a tiny minority of named shareholders. In effect, the introduction of the creamery very quickly converted the practice of butter making into a masculine occupation. ${ }^{36}$

In 1908, a damning indictment of the IAOS's failure to address the issue of female rural employment came from a former supporter of the movement. Fr Terence Connolly of Manorhamilton provided evidence to a royal inquiry in which he apologised for his role in starting co-operative creameries, on account of the fact he and others who supported the creamery failed to provide an alternative source of employment: 'where a girl was deprived of the industry of churning ... the idea was that she ... would be turned over at once to a cottage industry like lacemaking or sprigging or something of that kind. I think the issue has not been sufficiently followed up. ${ }^{37}$

The poultry industry represented another source of traditional female employment affected by the efforts to reorganise the countryside's economy. Poultry work was often a secondary occupation for the farm wife but it provided an important income stream. Joanna Bourke has highlighted an increase in poultry rearing between 1901 and 1911 by almost 20 per cent. ${ }^{38}$ However, these efforts to reorganise the poultry aspect of Irish agriculture often occurred without reference or regard to the interests of women. Women interpreted the IAOS's promotion of poultry co-operative societies as a means to convert egg production into another sphere of masculine influence. As Robert Anderson admitted in a speech delivered at the DATI's Poultry Conference in 1911, the IAOS:

was stupid enough to ignore the women and to attempt to secure an egg supply to a society composed of 'mere men.' In its early days (and we are still, alas! In those early days) every form of co-operative organisation came in for trade opposition. The Poultry-keepers' Societies were no exception to the rule. The womenkind resented the invasion of their domain by the men, and their passive resistance provided the egg dealers with the best possible weapon wherewith to attack this particular form of 'Plunkettism. ${ }^{39}$

Some co-operative societies offered limited employment roles as dairymaids, as shown in the photograph of the staff at Achonry Co-operative Society (figure 2.1). However, competition for positions proved fierce and a potential employee needed to demonstrate excellent credentials in order to avail of these opportunities. Sometimes those who applied for these positions did so out of frustration borne of a lack of work opportunities elsewhere. However, these positions remained scarce and could not meet the demand that existed among young women to move into employment. Debra Lyons of Dromahair, County Leitrim, had waited 


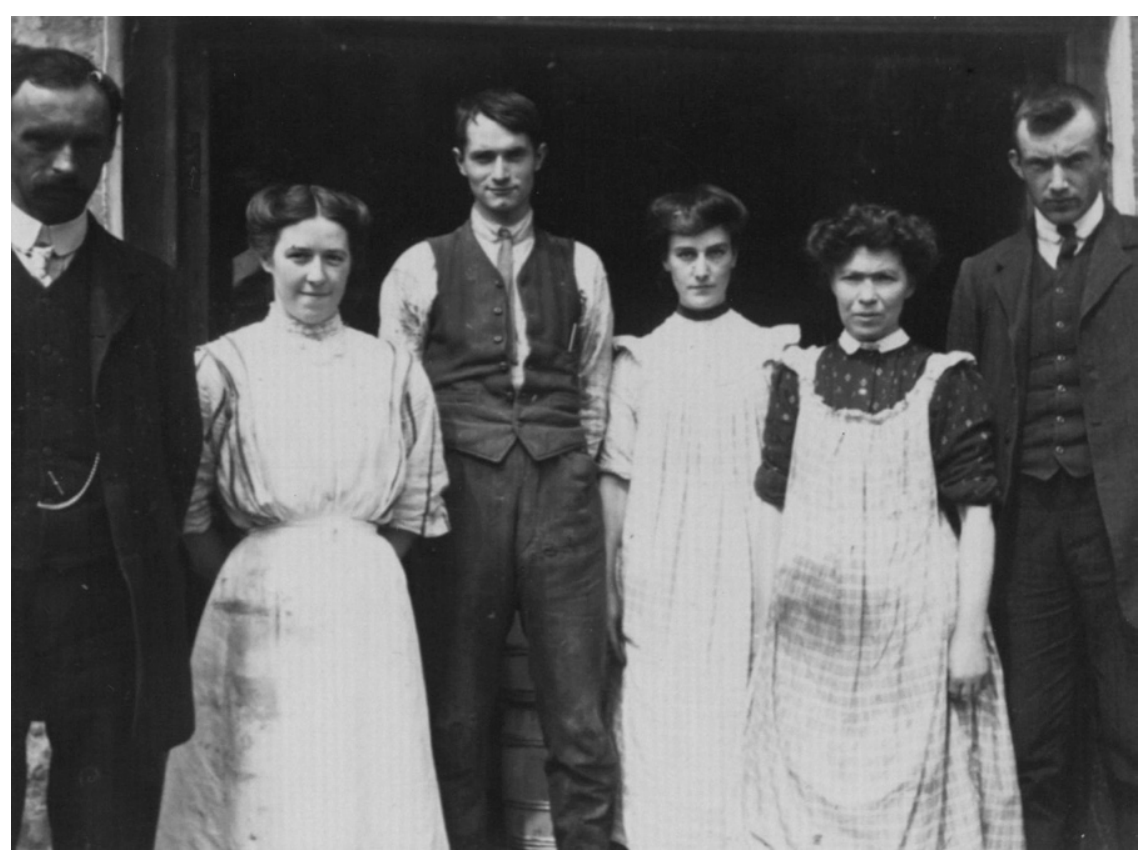

Figure 2.1 Employees outside Achonry Co-operative Creamery, ca. 1909

four years for an appointment as a female warder in the Irish prisons service but, owing to high demand in that sector, desired to retrain in dairying at Glasnevin. As she lacked the experience and money to enter the Glasnevin training institute she wrote to Josslyn Gore-Booth with his 'great interest in creameries' for help to obtain a position as an assistant dairymaid so that she might gain experience and income to support her application for the next intake. She explained that her father had died and she had no brother, and only she and two sisters lived on the farm. Enclosed testimonials from the local parish priest, rector, magistrate and Justice of the Peace acknowledged Lyons's 'steady, prudent, and industrious' character, but also suggested that the pursuit of such positions remained highly competitive and open only to those who could demonstrate a certain level of social respectability. ${ }^{40}$

Despite the inroads made by the creamery system, its concentration in the major dairying regions of Counties Limerick, Tipperary, Kilkenny, Sligo, Cavan, Monaghan, Cork, Leitrim, Kerry and Waterford meant that areas remained where the practice of home dairying continued into the twentieth century. The persistence of this older method of production provided scope for a leading female role in shaping the terms of modern butter production outside of the creamery system. During the 1900s, the DATI (see chapter 3) employed dairy instructors to 
travel to areas where hand dairying still proliferated. An instructor demonstrated modern methods in butter preparation to her audience, but as well as this, she performed an important role in the dissemination of public health information. The spread of tuberculosis remained a constant source of anxiety across Ireland throughout the early twentieth century and public health experts viewed the dairy industry as one culprit in the spread of that disease. Ellie Doyle was one such instructor who lectured dairymaids on how to manufacture and improve the quality of butter produced in the home so that they might compete with foreign butter producers. Doyle also provided instructive examples about how easily diseases like tuberculosis tainted milk and became 'very rapidly disseminated by the agency of impure milk; and how in each and every act performed by the dairymaid, the most scrupulous attention to cleanliness should be rigidly observed'. ${ }^{41}$

The role of women within the co-operative movement moved to centre stage following the publication of $Æ$ 's article 'Migration of Irishwomen from the Farm'. In that piece $Æ$ asked his readers to consider the reasons why Irish women emigrate from the countryside and controversially observed that 'while man's voice is uplifted loudly announcing his grievances, woman's voice is silent ... In Ireland women have hardly ever appeared on the political platform or added their diagnosis of what is wrong with us to the Irish man's loudly expressed tribulations. ${ }^{42}$ The article prompted a vocal response from female readers who castigated $Æ$ for speaking 'blather' with the added rejoinder 'cheap talk is what you are best at these times'. ${ }^{43}$ In April 1910 one correspondent, Ellice Pilkington, responded to Æ's provocation with a hope 'that you won't close your columns to "fair, fierce women," while you keep them open to - fierce men, who try to annihilate you. A great step is gained already as you are prepared to grant us "equality". 44

Later that year, Pilkington availed herself of an opportunity to address that year's IAOS conference on the women's question in the rural economy. The organisation, United Irishwomen (UI) was founded in the aftermath to direct the support women could offer to the extension of the co-operative movement. The first meeting of the new body took place in Bree, County Wexford on 30 September and Anita Lett was elected the first president. ${ }^{45}$ The UI aimed to work to prevent the continuation of female emigration out of Ireland. In a statement of the UI's working objectives, Pilkington argued along lines expressed by Plunkett in the past that the rural population 'must remain on the land, happily occupied, well employed, socially and intellectually developed. Here is permanent work for women to do. ${ }^{46}$ Pilkington viewed the UI as an auxiliary organisation to the IAOS and did not perceive of the role of the female in society in any revolutionary sense. Instead, she argued that among the UI 'none of us aspired to reform society or preach any gospel but that of domestic economy, good comradeship, and truth. ${ }^{47}$ 
The UI did perform important organisational work neglected by the IAOS. Miss Reynolds transferred from the IAOS to become the chief organiser on the UI staff. In this role, she worked to promote a more efficient distribution of milk to districts where 'it is impossible to procure even the most meagre supply for the children and babies, who are fed instead on black tea and bread'. In 1912, Reynolds established a UI branch in Fenit, County Kerry, which established a regular supply of milk for customers guaranteed by a local farmer. The average weekly amount delivered in November of that year was 112 gallons. She also established milk depots in Carlow and Omagh the same year. These depots immediately increased the circulation of milk in these undersupplied areas. In Omagh, the UI report noted that 'women from the country have walked 2 to 3 miles to buy the milk' ${ }^{48}$ In taking up the work of milk supply, instructing members in matters of domestic economy and organising social events, the UI provided another agency in the reorganisation of rural life.

The effect of the co-operative movement upon the culture of female work proved double-edged. On the one hand, the movement contributed to an ongoing process of reducing opportunities for female employment, particularly in dairying. Furthermore, the failure to address the question of female work at the level of the IAOS represented an institutional limitation that reflected the male composition of the movement's leadership. However, this resentment led to a serious if belated engagement with the question of the gendered structure of labour in the rural economy and led to women taking up the blunt and somewhat patronising challenge posed by $Æ$ in the Homestead. Despite this genesis, the opportunity to put forward the voice of women within a wider discussion of co-operation was seized by individuals such as Ellice Pilkington. Rural emigration remained a perennial problem, and the UI did little to change a popular perception that women should occupy a supporting role within the farm economy. Yet the foundation of the UI in 1910, although somewhat conservative in its views, represented an important landmark in a gendered approach to resolving socioeconomic questions. The organisation's existence, alongside the instructive work of female instructors, showed how women did influence the timbre of farm work, and provided an important platform for women to engage in debates about the condition of rural life.

\section{The IAOS and the generation of knowledge}

By the end of the nineteenth century, the co-operative movement established itself as the pre-eminent agent for agricultural modernisation. Despite instances of public outcry levelled at the IAOS on a national level, the movement remained a highly effective agent in promoting its agenda of rural reform. The IAOS's efforts to organise the people and resources of rural Ireland pointed to what Michel Foucault referred to as raison d'état. By this he meant 'a practice, or rather 
the rationalization of a practice, which places itself between a state presented as given and a state presented as having to be constructed and built'. ${ }^{49}$ To build an economy in which all future production and distribution would take place through co-operative businesses required the creation of new institutions supplemented with the propagation of new types of knowledge. From its inception the IAOS endeavoured to know as much about the countryside as possible. The IAOS obsessively measured and mapped the increase of co-operative activity in the reports that it published each year. Each report contained a detailed analytical breakdown for individual societies including where they were located, the size of membership, paid-up share capital, available loan capital and turnover. With the information generated, resources and support could be directed throughout the social network to rectify problems and shortcomings with a sophisticated degree of precision. Under Robert Anderson's guidance, a team of organisers, auditors, accountants, engineers and lecturers assisted the staff of the individual societies to ensure their business was administered effectively. As the movement expanded, the more detailed its portrait of rural life became and the more the responsibilities that rested with the IAOS staff grew. The organisers' reports provided the Dublin headquarters with detailed information about the condition of societies throughout Ireland. This allowed the IAOS to map a network of co-operative societies with a statistical breakdown of activity that made these transparent units eligible for purposes of statecraft. The annual reports of cooperative economic activity provided useful progress updates for those interested in the measurement and co-ordination of agricultural activity.

After the establishment of the DATI in 1899, the co-operative movement served as an important ally to state-led efforts aimed at the reform of the rural economy. The IAOS employed agricultural lecturers as part of its team of experts who imparted information about new agricultural techniques to members. Frequent inspections of creameries by organisers provided the IAOS headquarters in Dublin with a detailed snapshot of the condition of co-operative agriculture in practice. Within a few years, the IAOS proclaimed the 'progressive character' of their dairying societies that became centres of a scientific and rational approach to agricultural production: 'lectures given to Dairy Societies are crowded, the ordinary general meetings are well attended, experimental work is carefully watched, and its teaching intelligently applied'. ${ }^{50}$ The close relationship between the DATI and IAOS embodied by Horace Plunkett's leadership caused problems for the co-operative movement as it came under attack from traders, private creamery proprietors and Nationalist politicians who accused Plunkett of an abuse of power. ${ }^{51}$ Nevertheless, in the first six years of the DATI's existence, the IAOS's prominence in agricultural politics grew to such a level that it appeared inseparable from the Department.

Co-operative efforts in agrarian education produced important results over time and helped to foster a particular type of expertise focused around the site 
of the local co-operative creamery or agricultural society. Before the DATI started work the IAOS delivered a great deal of the technical instruction in agricultural matters, with instructors sent out to provide lessons on butter making, egg production, poultry rearing and other matters. This educational function of co-operation predated the DATI's work and the state department for agriculture represented an extension of the type of scientific progress pioneered by the IAOS - albeit an extension backed by public funds. This technical instruction continued after the DATI's establishment and the IAOS continued to disseminate information through the publication of leaflets. During 1903-04, the IAOS published eleven different leaflets, addressing a number of topics relevant to farmers' business. The subjects included information to encourage the building up of co-operative trade federations, cleanliness in the dairy, instructions on taking minutes and account keeping, and advice for the management committees. The instructive literature also contributed to the growing literature in the Irish language. That same year an Irish essay competition took place, in which participants wrote on the subject of co-operation, with the winning entry translated into English for the benefit of non-Irish speaking members. ${ }^{52}$ The educational impulse attached to the extension of co-operative farming allowed for the dissemination of farming methods to be trialled in a way that complemented later state expansion in the same field.

If the IAOS can be described as exhibiting a raison d'état then the chief figure in the performance of this was the organiser. The IAOS organiser proved vital to the growth of the movement. The demands placed upon the IAOS's limited financial resources meant that the body found itself 'compelled to refuse applications for organisers in many instances'. Nevertheless, from the outset organisers proved crucial to the achievement of the movement's sense of mission. When funds improved, the IAOS aimed to increase numbers of organisers 'to give the young Societies all the help needed during the first year or two, and to superintend the organisation of new societies. ${ }^{53}$ In its first twelve months, the IAOS's organisers addressed 315 meetings, out of which thirty-four societies were established. ${ }^{54}$ Plunkett addressed the fifth annual conference of the IAOS, satisfied with the figure of 40,000 farmers who 'accepted the self-help doctrine we have preached'. 55

The work to establish a new co-operative society started with an organiser's visit to address a local meeting of farmers and argue for the benefits of co-operation in business. This work required patience, tenacity and a thick skin as organisers faced a spectrum of interests opposed to the establishment of co-operative creameries or credit societies. These opponents included shopkeepers, butter merchants, private creamery owners and local politicians who viewed these new businesses as threats to their livelihoods. ${ }^{56}$ The co-operative organiser aimed to reorganise the countryside by encouraging farmers to act in concert to protect one another from the threat of these so-called 'gombeen-men'. The organiser's identification 
of the presence of an exploitative class in the Irish countryside mirrored a trope repeatedly found in the writings Irish cultural revivalists. John Millington Synge unflatteringly characterised this class of individual in a letter to his friend Stephen MacKenna:

There are sides of all that western life the groggy-patriot-publican-general shop-man who is married to the priest's half sister and is second cousin once-removed of the dispensary doctor, that are horrible and awful. This is the type that is running the present United Irish League anti-grazier campaign while they're swindling the people themselves in a dozen ways and then buying out their holdings and packing off whole families to America. ${ }^{57}$

As the public face of the IAOS, the organiser met with this local opposition. A local meeting organised for the purpose of a new society could expose and trigger a raft of local social conflicts. At Tralee in February 1895, Robert Anderson's efforts to exhort local farmers to establish a co-operative creamery met with stubborn resistance from one trader. Anderson delivered his pitch that the IAOS empowered farmers to engage in modern agricultural methods 'with the very smallest of expenditure and the maximum of profit'. The IAOS placed no money into the society but promised 'to supply all information to farmers starting the co-operative system'. After the meeting, a trader named Moynihan criticised Anderson in the press for misleading farmers. Moynihan argued vehemently against the co-operative creamery system as he claimed it produced an inferior product compared to 'well-made hand butter' and stated that a market 'glutted with creameries' will lead to the product 'sold at the price of grease'. The protest claimed that new creamery technology reduced the need for labour and thereby co-operation achieved the opposite intention its supporters claimed as it increased emigration and destroyed existent native industry. Moynihan argued that traders who 'supplied and backed up farmers in their times of adversity' received no recompense from the co-operative; and he asked 'how many men, how many trades, how many industries will be pauperised, and crippled out of existence?' Anderson tackled all of Moynihan's points in a reply published in the Kerry Sentinel and labelled Moynihan as someone who ostensibly wrote in the interest of the farming community' but more accurately appeared as 'a special pleader for the middleman'. ${ }^{58}$ Despite Anderson's efforts, Moynihan held back the cooperative movement in the market town - although societies were established in surrounding townlands in later years. Such frustrations occurred frequently for the IAOS organiser.

If a society was established then organisers regularly visited their assigned districts to inspect the performance of the co-operative businesses there. Whenever a society experienced any problems through a lack of knowledge, or a dispute arose between members, or if advice was required to pioneer a new branch of 
business the IAOS sent an organiser to facilitate. Therefore, it was essential that each organiser possessed an intimate understanding of the specific social and economic circumstances in each district to perform this role effectively:

It will be his business to have all kinds of local information at his fingers' ends - to know where the priest is friendly and where he is not, where the schoolmaster is competent, and where the gombeen-man is threatening. He must also know the weak points of the societies, and so be able to locate trouble without waste of time. $^{59}$

Communication between the IAOS in Dublin and co-operative societies throughout Ireland formed an integral feature of efforts to nurture a new civilisation.

The establishment of a creamery in this period did not mean that the form it took needed to be co-operative. As Cormac Ó Gráda and William Jenkins have pointed out, privately operated creameries proved to be the most numerous at the outset of the transformation of Irish dairying and maintained a source of fierce competition with the IAOS right through to the 1920 s. $^{60}$ Large dairying companies such as the Condensed Milk Company of Ireland had a sizeable market share of the dairying industry, particularly in Munster. ${ }^{61}$ The antagonism that existed between representatives of the IAOS and the private creameries spurred on the competition over the milk suppliers of the Irish dairying heartlands.

\section{The charismatic organiser}

Co-operative organisers drove economic development in Ireland by the creation of local networks of support. Geniality and personality proved major assets. The success or failure of an organiser's efforts partly reflected their ability to draw together figures of local influence and encourage new members to join a fledgling society. In some areas landlords still led the way. One notable landlord was Josslyn Gore-Booth of Lissadell, County Sligo. He came to Plunkett's attention in 1895 as a volunteer IAOS organiser for the Sligo area. ${ }^{62}$ Gore-Booth represented the type of progressive landlord that appealed to Plunkett's sensibilities - one who demonstrated concern and empathy for the welfare of his tenants. As one local newspaper reported, Gore-Booth led in the establishment of Drumcliffe Cooperative Society and 'ever since its inception worked incessantly for its success. Everything that a man could do has been done by this gentleman to improve the condition of the Drumcliffe people. ${ }^{63}$ As President of Drumcliffe Co-operative Society Gore-Booth championed the IAOS in the north-western region and was involved in the establishment of several other societies that included the Sligo District Co-operative Society, the Ballintrillick Co-operative Stores and the Irish Beekeepers' Association. He developed a close working relationship with other influencers, which included members of the clergy, and grew into a 
recognised source of intelligence on the development of the regional co-operative movement.

In the north-west of Ireland, competition between the IAOS and the private creameries created plenty of work for the co-operative organiser in the area, Henry Shaw. Counties Sligo, Roscommon and Leitrim had emerged as a battleground between the IAOS and the creamery firm, Lonsdale and Company, at the end of the nineteenth century. Shaw cultivated important relations with landlords and members of the Catholic clergy and hierarchy in order to promote the co-operative cause. During the summer of 1900, Lonsdale threatened to undermine co-operative creameries already established. Shaw used his contacts with creamery managers and employees in the region to keep abreast of Lonsdale's efforts to extend their businesses. These efforts included a plan to erect an auxiliary creamery near Achonry Co-operative Dairy Society. ${ }^{64}$ In a series of letters to Gore-Booth, Shaw explained his plan to disrupt Lonsdale's expansion. Shaw identified that a key broker in Lonsdale's plans was the local parish priest, Fr Scully, who had shown Lonsdale's agent, Mr Drake, around the region and introduced him to the local farmers. Shaw planned to reverse Scully's influence though his own connection to the Bishop of Achonry 'who is likely to hear something of this as he is very friendly to the movement and myself' ${ }^{65}$ Shaw later attended a meeting at Carrowmore School for the Achonry Coop Society 'to assist them keeping out Lonsdale who had got tenants consent for site (a man named McCann) to erect Auxiliary in the locality'. Shaw informed Gore-Booth that 'as the contemplated site is on Major O'Hara's property I shall have little difficulty in stopping that, and as Lord Harlich and yourself are the other Landlords I think we shall manage to keep them out' ${ }^{66}$ Lonsdale and Company continued to pose a threat to the IAOS in the area, but Achonry Co-operative Society strengthened their position against the company through the establishment of their own Auxiliary in the townland of Ballyara later that year.

The personality of the organiser proved to be an important, if immeasurable, aspect to their duties. In an ebullient passage George Moore described Æ's time in the field as someone who

rode through Ireland, preaching the doctrine of co-operation and dairy-farming from village to village winning friends to the movement with the personal magnetism which he exercises wherever he goes. As soon as he arrived in a village everybody's heart became a little warmer, a little friendlier; the sensation of isolation and loneliness, which all human beings feel, thawed a little; everybody must have felt happier the night that that kindly man mounted a platform, threw back his long hair, and began to talk to them, giving them shrewd advice and making them feel that he loved them and that they were not unworthy of his love.

To establish a society the organiser relied on his or her ability to foster effective and productive working relationships with individuals who possessed a high 
degree of social capital in a village. Again, Moore recalled that $Æ$ frequently lodged in the house of the priest when he made trips to address meetings, and his effect was such that

the lonely village priest, who does not meet a friend with whom he can exchange an idea once every three months, would spend a memorable evening with Æ. ... In the morning the old bicycle would be brought out, and away Æ would go, and the priest, I am sure, looked after him, sorry that he was going. ${ }^{67}$

Although Moore's recollections exhibit some affected exaggeration, members of the clergy proved to be important allies to the organiser. Fr Jeremiah O'Donovan explained how his own introduction to the co-operative movement, which 'he regarded as the most important work being carried on at present in Ireland', occurred when he learned about their work from the organiser P.J. Hannon. ${ }^{68}$ Parish priests and curates played an important brokerage role between the IAOS and the farmers. For example, the parish priest, Canon Ryan, chaired an IAOS meeting in the town of Emly, County Tipperary. The meeting 'resulted in those present signing applications for over $£ 500$ in shares in a co-operative society, to take over the disused creamery' ${ }^{69}$ At the first meeting of Kilflynn Co-operative Society, the local curate Fr Crimmins was elected the society's chair and promised to make a success of the new society. He commended the shareholders for 'appointing such, good sensible men' and promised the members 'there would be no friction, and that the creamery would be a great success, and would be seen very soon in the improved condition of the people (hear, hear)' ${ }^{70}$

The involvement of priests in running local societies proved a common feature of co-operative activity. For example, Ballaghderreen Co-operative Society maintained a priest in the positions of both president and vice-president in its formative years. Such tenures provided priests with one way to exert influence over local economic decisions, such as which individuals received positions of paid employment at the society. This authority might also be brought to bear on members' behaviour to increase economic efficiency at the creamery. At a meeting held to set the prices paid to farmers for the milk supplied, Fr Durkin, the vice-president, used his position to ensure the passage of a resolution that punished farmers who supplied low quality milk, potentially due to dilution. The motion threatened suppliers whose milk contained less than 3 per cent fat 'that if their standard does not improve the payment for their milk will be greatly reduced and won't be paid for at the rate of $3 d$. per Gal. any more'. ${ }^{71}$

A priest's leadership might provide the necessary encouragement that led people to support a co-operative business, but equally priests followed the advice of parishioners towards this direction. Fr James Neary, the parish priest for Frenchpark, responded to a letter from Josslyn Gore-Booth that inquired about the potential for a new creamery in that parish. The proliferation of co-operative creameries and auxiliaries acted as a buttress to contain the expansion of privately 
owned creameries such as Lonsdale's. Fr Neary possessed no expertise on the matter of economic co-operation before Gore-Booth's contact with him. Neary grew 'anxious to interview some intelligent persons in this Parish \& the surrounding Parishes'. When he discovered that all his sources of intelligence supported the co-operative system of dairying, he decided to help establish a new auxiliary society in his parish to supply Farrymount Co-operative Creamery three miles away. As Neary concluded in his letter to Gore-Booth, 'I certainly do not approve of the proprietary system - I am sure also that the people themselves will see that the Co-operative Creameries will be more profitable to them. ${ }^{72}$ The priest, then, could emerge as the most useful convert.

\section{Co-operative society as a site of local power}

Organisers frequently negotiated complex social relations to establish a new society. This required a strenuous and often protracted effort on their part as they aided new societies through the initial steps of incorporation and helped explain the rules. The time taken between establishment and a new society beginning its work could stretch to several months. During this transitional period the organiser remained alert and ready to deal with any emergencies that arose (such as mistakes due to lack of business experience among members) and to help defeat any challenges or attacks that might be aimed at the society in the meantime. ${ }^{73}$

Organisers also provided an impetus of leadership at the outset. For instance, at the first meeting of Ballaghderreen Co-operative Society Henry Shaw 'was received with prolonged cheering' when invited by the chairman, Fr O'Connor, to address the shareholders. Shaw outlined the importance of following IAOS procedures, but also offered advice on the character of the men the shareholders needed to elect to the committee, which showed the importance of the organiser in helping to establish the trajectory of these businesses:

he first reffered $[s i c]$ to the financial state of the society which was second to none on Ireland for the very short period working he then reffered [sic] to the election of committees and pointed out that 12 members i.e. -8 for Ballaghderreen +4 for Monasteraiden would be sufficient to manage the business of their society + he urged on the shareholders to elect only men of solvency + business tact men that could be relied on and if in cases of emergency secure overdrafts for their society from their Banker.

Shaw's speech provided the perfect introduction for Fr O'Connor, who proceeded to read out a list of men he recommended for the role of committee members. After they were read out a proposal was passed that allowed the names put forth to be accepted at once without going to a formal election. ${ }^{74}$

Co-operative society meetings acquired a notorious reputation. A satirical song entitled 'Tales from A Kerry Creamery' by 'Shemus' revolved around an imagined meeting and captured the colour of one of these events. The song focused upon the details of a meeting, told from a harassed secretary's point of 
view. Although published as a humorous appraisal of a co-operative meeting, the song suggests that while resentment of the way business was organised existed among certain farmers, sometimes violently expressed, very little happened to reform how societies operated. From the outset, the song's narrator establishes a picture of local disquiet:

Twas the day uv the Gineral Meetin', an' a stormy meeting too,

For we hadn't a pinny profit, an' the shareholders all looked blue;

From answerin’ curus queschuns me brain was addled quite -

Sure 'twas only the mercy o' heaven we hadn't a fakshun fight.

Local grievances are aired, accusations are made about the competency of the creamery's staff, and the dairymaid 'got a "rubbin' up" that she'll sartinly raymimber' - a casual indicator of the misogynist attitudes female employees might face at their place of work. However, the song concludes that the members accepted conditions as they existed before the meeting took place. Despite the fear that events might take a nasty turn, the final verse confirms the survival of the society and a return to business as usual: 'the ould Committee's ray-elected, an' the sthaff wor "let off wid a caution". 75 Society meetings offered members a local forum whereby dissatisfactions and jealousies were given a public hearing, but where ultimately order would be imposed by the methods prescribed by the society's conventions.

Co-operative societies came to represent sites of local power. Inclusion on the local committee proved an important indicator of an individual's importance within the community. However, committee members became visible targets for local resentment and meetings acquired a reputation as raucous affairs where local grievances were aired. For example, at Ballinclemessig Co-operative Society, one member physically assaulted the chairman. However, the society's solicitor advised the chairman from pursuing a legal action 'even though it would certainly aggravate the offence when the person assaulted was at the time chairman of a lawfully constituted meeting ${ }^{76}$ From the start of the movement's existence, local co-operative meetings assumed notoriety as lively social occasions and offered an opportunity for communal catharsis.

\section{The co-operative society as civilizing influence}

While organisers acted as intermediaries between individual societies and the IAOS, on a local level co-operative societies acted as intermediaries between local farmers and the marketplace. As the local creamery became a common sight across dairying regions, The Irish Homestead noted that 'a new rural personality has come into existence. The creamery manager will more and more become an influence in the country.' Managers constituted new rural authority figures on a par with 'the clergyman, the doctor and the schoolmaster'. Their role at the interface between members and the society's committee proved vital. Managers 
negotiated the short-term interests of the farmer by paying an acceptable 'fair' price for milk supplied, while ensuring the long-term sustainability of the society. The success of co-operation in Ireland relied upon local managers acquitting their duties in accordance with co-operative principles, as

[h] is employment is of a nature which tends to develop and widen out character. $\mathrm{He}$ is brought into contact with hundreds of farmers; and he alone perhaps in the community, through the fact of his being in direct contact with the greatest market in the world, and because he acts on behalf of the greatest industry in Ireland, is enabled to some extent to gauge the probable economic effect of certain political changes. ${ }^{77}$

The creamery manager occupied a unique position in Irish society. As the business's main official the manager acted as the connecting point between a district's butter producers and the marketplace beyond the village. Therefore, the success or failure of a co-operative creamery consisted in the ability to manage the expectations of members and fasten their support to the society, and to ensure that they met the demands of customers. While in early days prominent members of creameries, both co-operative and private, looked 'to get their own immediate friends and relations appointed to the principle positions, such as managers and dairymaids, whether properly qualified or not', this practice soon declined. It quickly became apparent that such appointments sowed discontent among suppliers and created an impression that nepotism and patronage operated at the creamery in a way that benefited some farmers over others. As William Stokes of the CWS noted at the end of the nineteenth century, it almost universally transpired that all appointments were made on merit 'and an unwritten but firmly established rule exists that those selected must have no connection with the locality or with any of the suppliers from the district' ${ }^{78}$

Ultimately, the co-operative society was a mechanism designed to instigate a revolution of Irish character. In The National Being, Æ emphasised the importance of the co-operative society's educational effects upon farmers. He conceived the character of Patrick Moloney in a polemical work that championed the co-operative model as the ideal arrangement for Irish society. Patrick Moloney represented a typical farmer who relied on the co-operative movement in order to shed the traditional superstitions that prevented his transformation into a co-operative subject. An important characteristic of co-operative organisation resided in the educational effect visited upon Patrick through constant interaction with the manager. Æ imagined that such contact encouraged Patrick to become

a member of a committee getting hints of a strange doctrine called science from his creamery manager. He hears about bacteria, and these dark invisibles replace, as the cause of bad butter-making, the wicked fairies of his childhood. ${ }^{79}$

Working through the co-operative society exposed farmers to arguments and ideas in favour of public health awareness, quality control and efficiency at the 
expense of the mythic aspects of a popular folk culture that other literary revivalists celebrated. ${ }^{80}$ Co-operative managers enlightened farmers about their old, traditional ideas and replaced them with new scientific norms that improved Patrick Moloney's industry.

One important aspect of scientific management resided in proficient numeracy and bookkeeping. The publication of accounts formed a legal requirement stipulated by the Industrial and Provident Societies Act and the task of maintaining a society's accounts fell to the manager. Candidates for managerial posts needed to demonstrate not only their ability to stay abreast of the latest advances in dairying techniques, bacteriology and engineering, but also demonstrate their competence in general business methods. ${ }^{81}$ In the early years of the movement's existence, a dearth of numerical and administrative expertise by management affected the performance of the movement. For example in 1905, John O'Connell, a Tralee-based solicitor, returned the business accounts sent for his inspection by the manager of Lixnaw Co-operative Society. O'Connell politely noted that a 'little confusion has arisen in this case owing to the form of the accounts furnished by you which of course no doubt are understood by you but not by everyone'. Helpfully, he wrote the figures in pencil, as he believed they should be presented. ${ }^{82}$

The quality and regularity of statistical returns from individual co-operative societies influenced how the IAOS conducted its work and prioritised its objectives each year. This accumulation of detailed information allowed the co-operative movement's leaders to read the movement and respond to shortcomings across the movement in a more directed and efficient manner. The statistical returns and balance sheets submitted by co-operative societies allowed the IAOS to judge the level of progress made by the movement based on annual year-on-year comparisons. Ten years into the IAOS's existence, the Executive Committee complained of 'the failure of a large number of societies to furnish statistical returns or balance sheet'. ${ }^{83}$ For example, fourteen of the thirty-seven registered co-operative creameries in County Limerick returned no statistical data for the year $1903 .{ }^{84} \mathrm{~A}$ decade later, however, the financial practices of societies improved due to regular interventions into society business by IAOS-appointed accountants. From 1907 onwards, the chief accountant, Andrew Swain, trained the other organisers in accountancy so that they could oversee the bookkeeping methods employed by individual societies. ${ }^{85}$ While still imperfect, the quality of the accounts submitted at the end of the financial year witnessed a marked improvement, especially in the case of creameries, in which the transactions are most numerous and complex and where a very complete and elaborate system of account keeping now prevails'. ${ }^{86}$

However, the IAOS complained that a dearth of good management material in Ireland was due to defects in the educational system. As late as 1922, the IAOS asserted that co-operative societies outnumbered good managerial candidates, 
'and pending the cultivation of such a new "race" of managers as is being cultivated in the creameries, a tremendous responsibility is thrown on the IAOS and its staff and on the committees of the societies'. ${ }^{87}$ In consequence, the experience of co-operative societies varied from district to district, owing to management decisions taken in regard to determining the quality of milk that farmers brought to the creamery and the prices paid for supplies. Other factors such as the presence of rival creameries affected how individual societies functioned, but a manager's ability to unify the membership behind a single purpose played an important role in the success of a co-operative enterprise.

By the first decade of the twentieth century the local co-operative society became an important site whereby new forms of social life were generated alongside experiments that promoted leisure time as a common good in a locality. To help along the 'brightening of rural life' Plunkett offered $£ 50$ prizes in 1901 and 1902 to the co-operative society that worked hardest to 'make their parish a pleasant place to live in, and one which no Irishman would like to emigrate from'. Dromahair Co-operative Society in County Leitrim secured the prize through its efforts to use educational means to raise 'their members to a higher social plane'. The efforts employed by this society over a six-month period saw lectures delivered on subjects such as poultry, horticulture, veterinary science, domestic economy and bee keeping. Attendees to these talks were treated to entertainments such as lantern presentations. A domestic training school for girls opened in the village of Creevelea with an average attendance of 44 girls; and a carpentry class for boys garnered an average attendance of 20. A series of entertainments that included a music festival, a concert and a cinematography exhibition took place and a farmers' circulating library was established. A series of other initiatives also launched in the locality, such as temperance drives, distribution of free flowers and shrubs, and 'a crusade against badly-kept homesteads'.

The IAOS played no direct role in the organisation of these social activities, which they viewed as evidence of 'one of the very best outcomes of the co-operative movement. We would not have achieved any real success if we had only united people for business purposes and they remained solitary and unsocial at heart. ${ }^{98}$ By the end of 1901, about thirty societies formed their own local lending libraries funded by grants offered by the DATI. ${ }^{89}$

Plunkett reflected on the IAOS's first decade in existence as evidence of the movement's success in this direction:

Those who have known Ireland for the last dozen years cannot have failed to notice the advent of a wholly new spirit, clearly based upon constructive thought, and expressing itself in a wide range of fresh practical activities.

These activities included the co-operative organisation of agriculture and rural credit, efforts to revive and initiate industries, and the creation of the DATI. Taken together, these changes encouraged, 'all that was healthy in the voluntary 
effort of the people to build up the economic side of their life'. ${ }^{90}$ Activity of this type that emerged out of the local co-operative society helped to create a version of an enlivened rural Ireland observed by the likes of Henry Demarest Lloyd and L. Paul-Dubois.

\section{The co-operative society and dissent}

Besides nurturing the practical side of co-operation, organisers faced situations whereby they needed to ensure that societies remained solvent in the face of challenges and internal problems. One such figure on the front line of co-operative organisation throughout the early twentieth century was Charles Riddall who worked as the organiser for the south-west of Ireland. ${ }^{91}$ Riddall's reports and communiqués formed the basis of the reservoir of detail about the state of agriculture available to the movement's executive in Dublin. Riddall devoted an extraordinary amount of energy to securing the permanence of co-operative organisation in that region and acted as the IAOS's chief negotiator for the takeover of creameries offloaded by the CWS in $1909 .{ }^{92}$ Riddall was able to befriend local individuals who could provide the information required to help local societies out of problems. He also demonstrated an earthy use of language in his efforts to commit support for co-operative societies. At Listowel, he addressed a meeting of co-operative supporters and stated that opposition to their proposed creamery came from persons 'tied to the proprietary concerns'. He characterised these people 'as worms rather than men ... [and] hoped, however, that they would soon be in a position to emancipate such unfortunate individuals from their serfdom and slavery'. ${ }^{93}$ As the IAOS fell back upon its own resources, the ability of organisers such as Riddall to negotiate compromises and find solutions to a range of problems that affected individual societies proved to be essential for the continuation of agricultural co-operatives during these years.

The prominence and notoriety achieved by co-operative societies meant they could become the recipients of violent attention as tensions bubbled under the surface of the Irish countryside and echoed the agrarian violence of the nineteenth century. ${ }^{94}$ One such society that experienced a rather volatile time during the first decade in operation was Ballinclemessig Co-operative Society in County Kerry. Founded in 1902, it started life amid acrimony. The first meeting held on 8 April 1902 immediately split the society on the issue of where the creamery should be located. Ballinclemessig won the support of a slight majority of members over the neighbouring village of Causeway. P.J. Hannon, the organiser present on that occasion, 'announced that any person who wished to withdraw could do so within 6 days' on account of the decision. The presence of a new co-operative could add prestige to the locality where it resided, particularly since a creamery housed modern technology and marked out its locality as a place of relative importance. Accordingly, the decision to locate this creamery in the townland of Ballinclemessig drew resentment from the Causeway inhabitants. The contentious 
decision led to the exodus of some initial members, including the provisional chairman, Fr McCarthy, and undoubtedly the decision bred resentment towards the new co-operative in its early years. ${ }^{95}$ The controversial introduction of the creamery to Ballinclemessig sowed the seeds of outrage against the society several years later. On the evening of 12 December 1908, an arson attack on Ballinclemessig Co-operative Society destroyed the entire premises and a former committee member emerged as the prime suspect for the attack. To compound the problem facing the co-operative farmers in the area, along with the loss of creamery equipment and account books, it emerged the committee had never taken out an insurance policy.

Riddall had fostered a professional relationship with the solicitor John O'Connell in order to keep himself informed of developments that affected the society. O'Connell worked in Tralee and included several of north Kerry's co-operative societies among his clients. He worked with Ballinclemessig Co-operative from its inception and possessed a detailed knowledge with regard to the background, personalities and grievances that characterised the society. O'Connell struggled to make progress with the case due to Ballinclemessig committee's failure to remain in regular communication with him. As a result, he bypassed his clients and contacted their organiser, Riddall, to whom he confided his personal view of the committee members:

I would request that you should remain in this district working up the case till matter is disposed of. Your assistance would be invaluable. The members of the Committee are very slow. I have heard nothing from them of late. They live a long distance from Tralee + like all men of their class they keep on delaying information ... till the last moment. One can hardly blame the poor men as they are mostly old and of very limited ability. ${ }^{96}$

The two men liaised together in order to bring the case to court. O'Connell's decision to approach Riddall shows how the sometimes 'poor men' who administered the society were bypassed in favour of the co-operative expert. O'Connell believed that 'the evidence as to malice is pretty strong. ${ }^{97}$ Charles Riddall went further when he wrote on the subject of Ballinclemessig: 'There is a great dispute between the Ballinclemessig and Causeway people over the purchase of Palmer and Elliott's [a private company] Ballinorig Creamery. ${ }^{98}$ The collapse of the local private creamery run by Palmer and Elliott meant that a new space had opened up in the dairy economy. Since Ballinclemessig's establishment, the co-operative had been involved in a rivalry with the local private concern and Riddall sensed that the collapse of this business related to outrage. Despite strong evidence of a break-in, Ballinclemessig Co-operative Society failed to secure a judgment in its favour and the former committee member was released.

Events like the destruction of a co-operative creamery could produce unexpected effects. At Ballinclemessig, the attack appeared to strengthen co-operative 
organisation within the community. The local population recognised the importance of the co-operative society to its economic interests and rallied around to ensure its survival. The society provided more than an outlet for milk supplies for local people. A creamery provided local employment and offered a range of services that included the purchase and marketing of local butter and provision of advance payments as a source of credit to farmers in lieu of milk to be received. ${ }^{99}$ Furthermore, the arson attack encouraged those people who had previously remained apart from the creamery to join the society. O'Connell noted that 'several persons who had refused to become shareholders before the burning have done so since'. ${ }^{100}$ The IAOS used Ballinclemessig in a propaganda exercise to emphasise the vibrancy of the co-operative ethos that existed among farmers in Kerry. The IAOS cited the inhabitants there as people who

nothing daunted by their misfortunes ... re-erected and re-equipped a most upto-date creamery in record time ... [T] his example of co-operative determination will be approved throughout the country. ${ }^{101}$

This episode demonstrated how quickly the new co-operative societies could be normalised within a locality such as Ballinclemessig.

Charles Riddall often provided a most valuable service to the IAOS by managing the sometimes contentious and complex local relations that coalesced around the co-operative society. At Newtownsandes Co-operative Society in north Kerry the committee considered the liquidation of the society following a scandal involving the creamery manager, John Houlihan. Before he left the society in January 1916, Houlihan destroyed the account books, which left the society in a precarious financial position. At 'a rather lively meeting' of the membership held to determine the future of the society, two members were ejected by members of the local constabulary who attended to watch over the proceedings. Charles Riddall also attended in an effort to preserve the future of the society. As the society's future hung in the balance Riddall reported to Dublin that members 'recognised however that the Society could not hope to keep its doors open unless the members did something more than give verbal undertaking to support it'. The situation required 'sufficient support in the shape of milk and money should be guaranteed by the members'. At that meeting held on 19 February 1916 , forty members present agreed to guarantee an overdraft extension to help the creamery through its immediate financial difficulties as it tried to work out the financial liabilities attached to the business. Furthermore, an advert was placed for a new manager and dairymaid. ${ }^{102}$

At the end of March Riddall returned to the district to ascertain the degree of progress. He discovered that the bank had refused an overdraft due to a lack of clarity on the financial position of Newtownsandes Society. Instead, members came together to agree to sign money bills to support the co-operative and a farmer with a large acreage, who supplied the local private Kerry and Cork 
Company's creamery, decided to donate $£ 6$ and agree to shift his milk supply to the co-operative. Furthermore, members agreed to forfeit all monies owed to them for December 1915, which amounted to a sum close to $£ 450$. Riddall wrote to Robert Anderson to explain that the people realised that the alternative to such measures was liquidation, which meant 'the establishment of another Creamery Proprietor in the district and that Co-operation would become for them a dead letter'. After the financial agreements were put in place the main obstacle to the co-operatives' continuation hinged on the membership's disagreement over the appointment of Thomas de Lacy as the new manager. Riddall refused to endorse de Lacy to the Newtownsandes committee in case he 'might cause dissension and undo all the work of reconstruction that had been so courageously and well done by the people themselves'. However, Riddall believed that de Lacy was the right man and therefore he organised a committee meeting at which he would endorse de Lacy, but before he attended he spoke to the local parish priest and curate. In Fr O'Carroll, the curate, Riddall found 'a sympathetic advisor'. The parish priest, 'an anti-co-operator' prevented Fr O'Carroll from open support for the co-operative society. O'Carroll advised Riddall to speak to other local men who he said would support the de Lacy appointment, and by the time Riddall later attended the committee meeting he found near unanimous support for the new manager.

Only one member of the Committee opposed this appointment, but after I had given my opinion of $\mathrm{Mr}$ de Lacy that member of the Committee proposed his appointment and another member of the Committee whom Father O'Carroll had 'talked round' seconded it and Mr de Lacy was then unanimously offered the position at $£ 120$ per annum plus a bonus out of the profits, the amount of which should be left to the discretion of the shareholders. ... The Committee expressed their appreciation of the work we had so far done for them and stated that had it not been for my presence at the meeting of shareholders on $19^{\text {th }}$ February last the Society would certainly have gone into liquidation. ${ }^{103}$

Certainly, in the early decades of the twentieth century the hard, repetitive work of spreading the co-operative gospel led to the creation of resilient socioeconomic institutions that characterised a new type of political economy. As new challenges that encompassed war, revolution and bitter communal violence arose over the course of the next decades the commitment of farmers to their societies would be severely tested.

\section{Notes}

1 'The Co-operative Village', Irish Homestead, 4 November 1905, 801-802.

2 'The Struggle between Country and Town', Irish Homestead, 15 August 1908, 645-666.

3 Fergus Campbell, The Irish Establishment, 1879-1914 (Oxford: Oxford University Press, 2009). 
4 Henry Demarest Lloyd, Labor Copartnership: Notes of a Visit to Co-operative Workshops, Factories and Farms in Great Britain and Ireland, in which Employer, Employé, and Consumer Share in Ownership, Management, and Results (London: Harper \& Brothers Publishers, 1898), 52.

5 L. Paul-Dubois, Contemporary Ireland (Dublin: Maunsel \& Co., 1908), 451.

6 Leeann Lane, "It is in the Cottages and Farmers' Houses that the Nation is Born": Æ's "Irish Homestead" and the Cultural Revival', Irish University Review, 33.1 (2003), 165-181 (p. 167).

7 Horace Plunkett, 'Rural Regeneration', North American Review, 214.791 (1921), 470-476 (p. 474).

8 Horace Plunkett, Noblesse Oblige: An Irish Rendering (Dublin: Maunsel \& Co., 1908), 26.

9 Thomas J. Morrissey, Thomas A. Finlay, SJ, 1848-1940: Educationalist, Editor, Social Reformer (Dublin: Four Courts Press, 2004).

10 IAOS, Annual Report, 1895, 3.

11 Líam Kennedy, 'The Early Response of the Irish Catholic Clergy to the Co-operative Movement', Irish Historical Studies, 21.81 (1978), 55-74 (p. 60).

12 Rerum Novarum: Encyclical of Pope Leo XIII on Capital and Labour, http:// w2.vatican.va/content/leo-xiii/en/encyclicals/documents/hf_l-xiii_enc_15051891_ rerum-novarum.html. [accessed 14 September 2017].

13 Horace Plunkett, Kildare Street Club to Archbishop Walsh, Dublin, 18 April 1894, Dublin Diocesan Archive (DDA), Walsh Papers, Box 255, 363/3.

14 'Among the Societies', Irish Homestead, 9 March 1895, 8.

15 Horace Plunkett, Dublin to Bishop Clancy of Elphin, Sligo, 2 June 1908, NLI, Ms 49,803/31/9.

16 Bishop MacCormack's Notebook, 30 April 1895, Galway Diocesan Archive, Box 22.

17 Kennedy, 'The Early Response', 60.

18 Horace Plunkett, Ireland in the New Century: with an Epilogue in Answer to Some Critics (London: John Murray, 1905), 107.

19 R.A. Anderson, With Horace Plunkett in Ireland: The Co-op Organisers' Story (London: Macmillan and Co., 1935), 150.

20 Dermot Meleady, John Redmond: The National Leader (Dublin: Merrion, 2014), 65.

21 Special Committee Meeting, 25 August 1904, Gore-Booth IAOS Papers, 1904, PRONI, D/4131/M/15.

22 Horace Plunkett, Dublin to Bishop O’Dwyer, Limerick, 8 March 1904, Limerick Diocesan Archive, BI/ET/K.

23 Plunkett Diary, 5 April 1904.

24 Plunkett Diary, 29 March 1904.

25 R. Barry, P.P., 'Sir Horace Plunkett on the Influence of Religion', Freeman's Journal, 1 March 1904, 2.

26 Plunkett Diary, 7 March 1904.

27 Plunkett Diaries, 5 April 1910; Kennedy, 'The Early Response', 60.

28 Anderson, With Horace Plunkett, 150.

29 Cited in Morrissey, Thomas A. Finlay, 95. 
30 IAOS, Annual Report, 1904, 24-25.

31 'Mr Horace Plunkett's Disorganization Society Limited', Skibbereen Eagle, 12 October $1895,2$.

32 'Our Programme', Irish Homestead, 9 March 1895, 3-5.

33 'Among the Societies', Irish Homestead, 9 March 1895, 6.

34 George Moore, Hail and Farewell! Ave, Salve, Vale (Gerrards Cross, Bucks.: Colin Smythe Ltd, 1985 [1911]), 302-303.

35 Nicholas Allen, George Russell (E) and the New Ireland, 1905-30 (Dublin: Four Courts Press, 2003), 27-29.

36 Joanna Bourke, Husbandry to Housewifery: Women, Economic Change, and Housework in Ireland, 1890-1914 (Oxford: Clarendon Press, 1993), 87-88.

37 Cited in Bourke, Husbandry to Housewifery, 102.

38 Bourke, Husbandry to Housewifery, 196-197.

39 DATI, Conference on the Poultry Industry, Dublin, May, 1911: Report of Proceedings (London: HMSO, 1911), 125.

40 Debra Lyons, Dromahair, to Josslyn Gore-Booth, Lissadell, 24 August 1900, Gore-Booth, Drumcliffe Co-operative Dairy Society and Related Papers, PRONI, D4131/M/11B.

41 'Lecture and Demonstration in Dairying at Kilflynn', Kerry Sentinel, 29 June 1904.

42 'Migration of Irish Women from the Farm', Irish Homestead, 22 January1910, 61.

43 An Irish Woman of 1910, 'A Castigation', Irish Homestead, 5 February 1910, 109-110.

44 Ellice Pilkington, 'The Irish Countrywoman', Irish Homestead, 9 April 1910, 294.

45 'United Irishwomen', Irish Homestead, 8 October 1910, 844-845.

46 Ellice Pilkington, 'United Irishwomen - Their Work', in Horace Plunkett, Ellice Pilkington and George Russell (eds), The United Irishwomen: Their Place, Work and Ideals (Dublin: Maunsel \& Co., 1911), 19-35 (p. 20).

47 Ellice Pilkington, 'United Irishwomen - Their Work', 22.

48 The Society of the United Irishwomen, Annual Report, 1912 (Wexford: The People, 1913), 4.

49 Michel Foucault, The Birth of Biopolitics: Lectures at the College de France, 1978-1979 (Houndmills, Basingstoke: Palgrave Macmillan, 2010), 4.

50 IAOS, Annual Report, 1901, 16.

51 Líam Kennedy, 'Farmers, Traders and Agricultural Politics in Pre-Independence Ireland', in Irish Peasants: Violence and Political Unrest, 1780-1914, ed. by James S. Donnelly Jr and Samuel Clark (Manchester: Manchester University Press, 1983), 339-373.

52 IAOS, Annual Report, 1904, 25.

53 IAOS, Annual Report, 1895, 5.

54 Lionel Smith-Gordon and Laurence C. Staples, Rural Reconstruction in Ireland: A Record of Co-operative Organisation (London: P.S. King and Son, 1917), 63.

55 IAOS, Annual Report, $1899,7$.

56 Kennedy, 'Farmers, Traders and Agricultural Politics'.

57 Ann Saddlemyer (ed.), The Collected Letters of John Millington Synge: Volume One, 1871-1907 (Oxford: Oxford University Press, 1983), 116.

58 'Among the Societies, Tralee', Irish Homestead, 9 March 1895, 6-7. This article republished Moynihan's letters to the Kerry Sentinel verbatim. 
59 Smith-Gordon and Staples, Rural Reconstruction, 67.

60 Cormac Ó Gráda, 'The Beginnings of the Irish Creamery System, 1880-1914', Economic Review of History, 30.2 (1977), 284-305; William Jenkins, 'Capitalists and Co-operators: Agricultural Transformation, Contested Space, and Identity Politics in South Tipperary, Ireland, 1890-1914', Journal of Historical Geography, 30 (2004), 87-111.

61 Ingrid Henriksen, Eoin McLaughlin and Paul Sharp, 'Contracts and Co-operation: the Relative Failure of the Irish Dairy Industry in the Late Nineteenth Century Reconsidered', European Review of Economic History, 19.4 (2015), 412-431.

62 Plunkett Diary, 2 August 1895.

63 Sligo Independent, 24 October 1896. Contained in a selection of press extracts kept in Gore-Booth Papers, PRONI, D4131/M/11A.

64 Auxiliaries were smaller societies that sent milk from one area to a larger central creamery.

65 Henry Shaw, Ballymote to Josslyn Gore-Booth, Lisadell, 5 May 1900, PRONI, D4131/M/11B.

66 Henry Shaw, Ballymote to Josslyn Gore-Booth, Lisadell, 11 June 1900, PRONI, D4131/M/11B.

67 Moore, Hail and Farewell, 303-304.

68 'Dinner to Mr P.J. Hannon', Irish Homestead, 26 August 1905, 647.

69 'From our Organisers' Diaries', Irish Homestead, 6 April 1895, 70-71.

70 'Kilflynn Co-operative Dairy Society', Irish Homestead, 2 January 1904.

71 Ballaghderreen Co-operative Agricultural and Dairy Society - Minute Book, 7 August 1906, National Archives of Ireland, BR/ROS/12/1.

72 Fr James Neary, Frenchpark to Josslyn Gore-Booth, Lissadell, 24 April 1899, GoreBooth Papers, PRONI, D4131/M/11B.

73 Smith-Gordon and Staples, Rural Reconstruction, 66.

74 First General Meeting of shareholders, Ballaghderreen Courthouse. Ballaghderreen Co-operative Agricultural and Dairy Society - Minute Book, 11 January 1900, National Archives Ireland [NAI] BR/ROS/12/1.

75 Shemus, 'Tales of a Kerry Creamery', in A Celtic Christmas: The Irish Homestead Christmas Number, ed. by H.F. Norman (Dublin: Irish Agricultural Organisation Society, 1898), 17-18.

76 John O’Connell, Tralee, to the Michael O'Connor, Secretary, Ballinclemessig Cooperative Dairy Society, 12 October 1910, KLHA, O’Connell Papers.

77 'Creamery Managers', Irish Homestead, 9 December 1905, 883.

78 W.L. Stokes, 'Irish Creameries', in CWS, Annual Report, 1897 (Manchester: CWS, 1897), 419-449 (p. 426).

79 Æ, The National Being: Some Thoughts on an Irish Polity (Dublin: Maunsel \& Co., 1916), 25.

80 Yeats was criticised for celebrating the peasant belief in fairies. He defended literal belief in such phenomena, citing rationalism as the 'great sin against art'. R.F. Foster, W.B. Yeats: A Life, I: The Apprentice Mage, 1865-1914 (Oxford: Oxford University Press, 1997), 77.

81 Creamery Managers, Sample Examination Timetable, March 1919, NAI/AGF/92/ $2 / 1573$. 
82 John O'Connell, Tralee, to the Manager of Lixnaw Co-operative Society Dairy Society, 4 February 1905, KLHA, O’Connell Papers.

83 IAOS, Annual Report, 1904, 10.

84 IAOS, Annual Report, 1904, 76-77.

85 IAOS, Annual Report, 1907, 15.

86 IAOS, Annual Report, 1914, 6.

87 IAOS, Annual Report, 1922, 15.

88 IAOS, Annual Report, 1901, 39-41.

89 IAOS, Annual Report, 1901, 42

90 Plunkett, Ireland in the New Century, viii.

91 IAOS, Annual Report, 1907, 15-16.

92 IAOS, Annual Report, 1909, 6.

93 Kerry Sentinel, 20 January 1909.

94 Margaret O'Callaghan, British High Politics and a Nationalist Ireland: Criminality, Land and the Law under Forester and Balfour (Cork: Cork University Press, 1994).

95 Undated note, $c .1902$, detailing observations about first meeting of Ballinclemessig Co-operative Society, KLHA, O’Connell Papers.

96 John O'Connell to C.C. Riddall, 20 January 1909, KLHA, O’Connell Papers.

97 John O'Connell, Tralee to Michael O’Connell, Causeway, 15 February 1909, KLHA, O'Connell Papers.

98 C.C. Riddall to R.S. Tarrant, Dublin, 6 March 1909, NAI 1088/800/2.

99 John O'Connell, Tralee to Michael O'Connor, Rathmorrel, 24 September 1907, KLHA, O'Connell Papers.

100 John O'Connell, Tralee to Registrar of Friendly Societies, Dublin, 6 April 1909, KLHA, O'Connell Papers.

101 IAOS, Annual Report, 1909, 9.

102 C.C. Riddall's Report of Visit to Newtownsandes Co-operative Society, 10 March 1916, NAI 1088/751/3.

103 C.C. Riddall's Report of Visit to Newtownsandes Co-operative Society, 28 March 1916, NAI 1088/751/3. 